z zachowaniem suwerenności przez jego części składowe, znajduje odbicie w rdzeniu politycznym Unii Europejskiej i okalającą go Organizacją Państw Europejskich. Zastanawia fakt, że Autor używa słowa „konstytucja” tylko w kontekście Projektu Traktatu Konstytucyjnego, swoich propozycji nie podnosi do rangi konstytucyjnych, lecz, jak się wydaje, pozostawia wolną rękę, ewentualnemu przyszłemu Konwentowi, co do sposobu i rangi ich skodyfikowania.

Książka została wydana w Polsce w pierwszym kwartale 2007 roku przez wydawnictwo demosEuropa. Jej promocja w Polsce odbiła się szerokim echem w środkach masowego przekazu, jak również przed i po wizycie Autora w Polsce. Książka liczy 90 ponumerowanych stron, jest podzielona na krótkie rozdziały poprzedzone wstępem i opatrzone podsumowaniem. Język nie zawiera trudnych sformułowań, co pozwala na lekką, ale wymagającą zaangażowania, lekturę. Zdaniem autora recenzji, czytelnikami książki winni być studenci stosunków międzynarodowych, politologii, administracji europejskiej i in. zainteresowani formułowaniem się nowego porządku w Unii Europejskiej i w świecie. Książka winna też trafić do rąk teoretyków i praktyków integracji, zaliczając też do tej drugiej grupy polityków, przedstawicieli Państw Członkowskich Unii. Guy Verhofstadt nie poczynił wielkiego dzieła naukowego, jednak opisał swoje przemyślenia na temat Unii Europejskiej, i to, z punktu widzenia myślenia o jej przyszłym kształcie, nie pozwala na pominięcie tej pozycji książkowej.

MIKOLAJ J. TOMASZYK

Poznań

\title{
Zbigniew Czachór (red.), Unia Europejska po Traktacie ustana- wiajacym Konstytucje dla Europy, Wydawnictwo INPiD UAM, Poznań 2006, ss. 167.
}

Traktat ustanawiający Konstytucję dla Europy (dalej zwany Traktatem Konstytucyjnym) był kolejną z rzędu, lecz tym razem nieudaną próbą, reformy podstaw prawnych funkcjonowania Unii Europejskiej. Po wcześniejszym Traktacie z Amsterdamu i Nicei, które nie wypełniły postawionych przed nimi zadań, przywódcy państw członkowskich UE na posiedzeniu Rady Europejskiej w Laeken w grudniu 2001 r. zdecydowali się na nowy sposób przygotowania zmian w prawie pierwotnym, tj. poprzez przygotowanie propozycji rozwiązań poprzez Konwent mający być ciałem przedstawicieli obywateli Unii Europejskiej. Jednakże z powodu odrzucenia tzw. Konstytucji Europejskiej w referendach przez obywateli Francji i Holandii oraz rezygnacji przywódców z prób ożywienia Traktatu, Konstytucja Europejska przeszła do historii.

Praca zbiorowa jest dziełem autorów artykułów, którzy są pracownikami albo doktorantami Instytutu Nauki Politycznych i Dziennikarstwa UAM. Jednakże wśród autorów znajdują się także osoby z innych ośrodków naukowych z Republiki Federalnej Niemiec (Uniwersytet z Poczdamu oraz Uniwersytet Humboldtów z Berlina).

Pierwszy artykuł redaktora zbioru pt. Sfera wewnętrznej i zewnętrznej aktywności Unii Europejskiej po Traktacie ustanawiajacym Konstytucję dla Europy zamieszczony w książce jest swoistym zwornikiem całej zawartości zbioru. Autor koncentruje się w pierwszej części na analizie prawnej tego, czym z założenia miał być Traktat Konstytucyjny, odnosząc się do jego nazwy, w której ważnym elementem jest słowo „konstytucja” oraz znaczenia jakiego nabiera ono w kontekście powiązania ze słowem „traktat” dla Unii Europejskiej. W dalszej części artykułu mamy zaprezentowaną analizę postanowień Traktatu Konstytucyjnego w Obszarze Wolności, Bezpieczeństwa i Sprawiedliwości oraz przestrzeni działań zewnętrznych i polityki bezpieczeństwa i obrony UE.

Następny artykuł w pracy nosi nazwę Tożsamość zbiorowa w Unii Europejskiej, w którym I. Paweł Karolewski analizuje powiązanie tożsamości zbiorowej z modelem obywatelstwa. 
Zgodnie z tezą Autora istnieje możliwość przypisania zbiorowej tożsamości nie tylko państwom narodowym, z którymi to pojęcie jest związane, ale także z innymi systemami politycznymi, natomiast istnienie $\mathrm{i}$ intensywność owej tożsamości związane jest modelem obywatelstwa, które jest specyficzne dla konkretnego typu systemu politycznego. Dla potwierdzenia owej tezy prezentowane zostają i poddane analizie trzy modele (,typy idealne”) obywatelstwa: republikański, liberalny i cesarski oraz określony na bazie tych trzech modeli charakter obywatelstwa Unii Europejskiej. Autor wskazuję przede wszystkim na znacznie pierwszego modelu obywatelstwa dla budowy tożsamości zbiorowej w Unii.

Artykuł Jolanty Bryły pt. Relacje transatlantyckie $w$ zakresie rozwiqzywania wybranych problemów międzynarodowych prezentuje stosunki pomiędzy Stanami Zjednoczonymi oraz Unią Europejską w trzech kluczowych dla kontaktów transatlantyckich kwestiach. Po pierwsze, problemu proliferacji broni masowej zagłady; po drugie, terroryzmu międzynarodowego oraz po trzecie, globalnych zmian klimatycznych. Autorka zwraca uwagę na pogorszenie się stosunków wzajemnych po objęciu władzy przez George’a W. Busha, gdyż po tym wydarzeniu jeszcze bardziej wyostrza się sytuacja, w której zagrożenia dla bezpieczeństwa definiowane przez oba podmioty są praktycznie tożsame, jednakże sposoby ich rozwiązywania są zasadniczo odmienne.

Genezę, znaczenie oraz unormowanie praw podstawowych Unii Europejskiej w omawianym zbiorze analizuje artykuł Adama Szymaniaka Karta Praw Podstawowych Unii Europejskiej. Autor przede wszystkim wskazuje na zakres praw, jaki w założeniu Karta miała gwarantować obywatelom Unii Europejskiej oraz ewentualne możliwości kontroli przestrzegania tych praw. Bardzo ważnym elementem jest wskazanie na postawy polityków i komentatorów, co do przedmiotu i znaczenia Karty dla ochrony praw człowieka na kontynencie europejskim. Już na sam koniec warto przypomnieć, że Karta została włączona do Traktatu z Lizbony, a więc ma szanse stać się wkrótce, pomimo upadku idei Traktatu Konstytucyjnego, obowiązującym prawem.

W kolejnym artykule pt. Przyszłość integracji europejskiej w kontekście polityki spójności Unii Europejskiej Krzysztof Senger bada zależność pomiędzy postępem integracji a wzrostem spójności wewnątrz Unii Europejskiej. W dalszej części analizuje nowe cele polityki regionalnej w okresie programowania na lata 2007-2013, wskazując na nacisk, jaki został położony na zapewnienie rozwoju zasobów ludzkich w realizacji nowej polityki regionalnej. W ostatniej części artykułu rozpatrywany jest stosunek integracji do zjawiska globalizacji. Zgodnie z tezą Autora możemy mówić o ścisłym powiązaniu tych dwu zjawisk jako wpływających pozytywnie na siebie, a nie stanowiących swoje przeciwieństwa.

Artykuł Mikołaja Tomaszyka Perspektywy rozwoju Unii Europejskiej-od Traktatów Rzymskich do projektu Traktatu Konstytucyjnego jest wielowątkowy. Autor stawia sobie za cel wskazanie perspektyw rozwoju dla Unii po negatywnych wynikach referendów w dwóch państwach członkowskich oraz znaleźć źródła legitymizacji i bytności Unii Europejskiej po upadku systemu komunistycznego i zniknięciu podziału świata na dwa antagonistyczne bloki. Jednakże pierwszym elementem prezentowanym $w$ artykule jest analiza wyzwań stojących przed Unią Europejską (m.in. globalizacji). Jako perspektywy rozwoju integracji europejskiej są wskazane: rozszerzanie składu członkowskiego o nowe państwa oraz udzielenie odpowiedzi przez najwyższych przedstawicieli państw członkowskich, co do celu konstrukcji, jaką jest Unia Europejska.

Kolejną częścią w omawianym zbiorze jest artykuł Moniki Mardas Mechanizmy zarzqdzania ekonomicznego UE a Traktat Konstytucyjny. Autorka prezentuje problematykę: ewolucji systemu finansowania Wspólnot Europejskich, uregulowań prawnych dotyczących sfery finansów w Unii, budżetu Wspólnoty m.in. w zakresie jego konstrukcji, procedury uchwalania oraz zmiany niesione przez Traktat Konstytucyjny. Główna teza prezentowana w artykule głosi, iż zmiany niesione przez Konstytucję Europejską w zakresie regulacji materii finansów Unii nie są zmianami rewolucyjnymi. W ocenie Autorki jest to negatywne zjawisko, gdyż finanse Unii potrzebują reformy, której owe propozycje nie przynosiły. 
Artykuł Anny Potyrały Wspólny Europejski System Azylowy jest analizą uregulowań prawnych w Unii Europejskiej w zakresie problemów uchodźców. Autorka w pierwszej części pokrótce prezentuje historyczne przesłanki zainteresowania Unii tą kwestią. W kolejnej odnosi się do umów dotyczących uchodźstwa, których stronami są państwa członkowskie UE oraz postanowień normatywnych na szczeblu UE. Dalszą część artykułu stanowi analiza faktycznego funkcjonowania ustanowionego Wspólnego Europejskiego Systemu Azylowego. W ocenie Autorki utworzenie wspomnianego systemu jest wydarzeniem przełomowym w podejściu państw członkowskich do problematyki uchodźców, jednakże faktyczne jego działanie mocno odbiega nadal od założeń postawionych przed tym systemem.

Dyskurs europejski w Szwecji autorstwa Andrzeja Marcina Szuszyckiego analizuje dwie kwestie: strukturę dyskursu politycznego dotyczącego zagadnień integracji europejskiej w Szwecji oraz stopień rozwoju tożsamości europejskiej wśród elit politycznych Szwecji. W pierwszej części artykułu zaprezentowano problemy definicyjno-teoretyczne. Zgodnie z tezą Autora dyskurs wpływa w decydujący sposób na definiowanie swej tożsamości przez jednostki ludzkie. Kolejnym elementem jest analiza postaw i preferencji przedstawicieli partii zasiadających w parlamencie Szwecji oraz przywiązania do fundamentalnych wartości UE. W ocenie Autora to właśnie poprzez analizę przywiązania do wartości fundamentalnych UE najlepiej określać tożsamości europejską, a nie poprzez mierzenie poparcia dla przekazywania funkcji państwa narodowego na poziom supranarodwy.

Artykuł Jarosława Jańczaka Administracja, procedury decyzyjne, parlament - reformy Republiki Finlandii jako rezultat czlonkostwa w UE prezentuje wpływ integracji europejskiej na zmianę systemu politycznego Finlandii. Główne akcenty zostają położone na analizę: czynników wewnętrznych i zewnętrznych oddziaływujących na zmianę systemu politycznego, dostosowanie administracji do wymogów funkcjonowania Finlandii jako państwa członkowskiego UE oraz kształtowanie polityki zewnętrznej z perspektywy państwa członkowskiego. Zgodnie z wnioskami Autora w Finlandii mamy do czynienia z pewną anomalią zmiany systemu politycznego $\mathrm{w}$ związku $\mathrm{z}$ integracją europejską analizowaną $\mathrm{z}$ perspektywy międzyrządowej szkoły teorii integracji, gdyż dochodzi do wzmocnienia roli parlamentu, a nie rządu, co głosi wspomniana teoria. Przyczyny tego faktu upatrywane są w ewolucji systemu semiprezydenckiego ku systemowi parlamentarno-gabinetowemu.

Artur Wejkszner w artykule USA - Unia Europejska. Wymuszone partnerstwo czy walka o hegemonię? Zastanawia się nad charakterem relacji pomiędzy USA a UE, starając się odpowiedzieć na pytanie czy przewagę w nich mają elementy rywalizacji czy może elementy pragmatycznego podejścia do współpracy. W początkowej części artykułu Autor prezentuje najważniejsze czynniki kształtujące stosunki wzajemne wypływające jeszcze z czasów zimnej wojny. W dalszej kolejności Autor podejmuje problematykę stosunków postzimnowojennych, jako element graniczny ich otwarcia wymienia Deklarację transatlantyckq z 1990 r. Bardzo istotnym elementem analizy relacji wzajemnych jest współpraca gospodarcza pomiędzy UE a USA, co stanowi ważny element współpracy między tymi podmiotami, w przeciwieństwie do znacznie trudniejszej współpracy polityczno-miltarnej. Według Autora w nadchodzącej przyszłości w stosunkach USA-UE przewagę osiągną czynniki współpracy między tymi podmiotami.

Oceniając wartość całego zbioru na początek należy zwrócić uwagę, iż sformułowanie zawarte w jego tytule odnosi się do pewnej sytuacji w Unii Europejskiej, w państwach członkowskich UE oraz jej otoczeniu zewnętrznym, jaka zaistniała po podjętej próbie reformy traktatowej związanej z przygotowaniem Konstytucji Europejskiej. Tym samym zawartość zbioru prezentuje różne aspekty funkcjonowania Unii Europejskiej i państw członkowskich w aspekcie integracji europejskiej, a nie skupia się tylko na samym Traktacie Konstytucyjnym, co jest bez wątpienia ogromnązaletą tej publikacji. Ważnym elementem jest różne podejście metodologiczne autorów artykułów, gdyż pozwala ono zauważyć pewne nowe trendy związane z tego typu publikacjami, w dużej części jest to związane z faktem wspomnianym na wstępie, tj. udziałem w publikacji osób z instytucji naukowych z Niemiec. 
Książka Unia Europejska po Traktacie ustanawiajacym Konstytucje dla Europy jest wielowątkową publikacją odwołującą się do obecnego stanu integracji europejskiej, funkcjonowania państw narodowych w powiązaniu z Unią Europejską oraz stosunków zewnętrznych Unii, godną polecenia każdemu zajmującemu się problematyką Unii Europejskiej.

ADAM JASKULSKI

\section{Irma Slomczyńska, Europejska Polityka Bezpieczeństwa i Obrony. Uwarunkowania, struktury, funkcjonowanie, Wydawnictwo Uni- wersytetu Marii Curie-Skłodowskiej, Lublin 2007, ss. 408.}

Pierwotnym obszarem, w którym dokonywała się integracja europejska była sfera gospodarcza. Pomimo, że już w latach 50-tych XX wieku podejmowano próby zacieśniania współpracy w zakresie polityki zagranicznej i bezpieczeństwa, z powodów oporów przede wszystkim Francji, początki współpracy politycznej państw członkowskich Wspólnot Europejskich datuje się na lata siedemdziesiąte XX w. Przełomem w tej współpracy był Traktat z Maastricht, który wprowadzał postanowienia o Wspólnej Polityce Zagranicznej i Bezpieczeństwa (WPZiB), tzw. „II filar”'Unii Europejskiej. Jednakże postanowienia o WPZiB, które weszły w życie w 1993 r. bardzo szybko zostały negatywnie zweryfikowane przez nieporozumienia i brak współpracy pomiędzy państwami członkowskimi UE.

Podjęte próby zmiany nieefektywnych zapisów Traktatowych związane były m.in. z zabiegami mającymi na celu stworzenie struktur militarnych i wyposażenia Unii w zdolności bojowe w celu prowadzenia operacji wojskowych. Początkowo starano się zgodnie $\mathrm{z}$ koncepcją przyjętą $\mathrm{w}$ roku 1993 powiązać UE z reaktywowaną Unią Zachodnioeuropejską. W późniejszym okresie zrezygnowano jednak z tych zamiarów i po porozumieniu brytyjsko-francuskim doszło do powołania w ramach WPZiB na podstawie art. 17 TUE Europejskiej Polityki Bezpieczeństwa i Obrony (EPBiO).

Książka Irmy Słomczyńskiej Europejska Polityka Bezpieczeństwa i Obrony. Uwarunkowania, struktury, funkcjonowanie podejmuje właśnie problematykę zagadnienia, jakim jest tworzenie polityki bezpieczeństwa i obrony, która zgodnie z zapisami Traktatu o Unii Europejskiej, może w przyszłości prowadzić do wspólnej obrony.

Omawiana książka podzielona jest na trzy części, z których każda składa się z trzech rozdziałów podzielonych na podrozdziały. Oczywiście całość dopełnia wprowadzenie i podsumowanie oraz bibliografia, spis rysunków i tabel.

Część pierwsza poświęcona jest uwarunkowaniom EPBiO. Autorka w trzech rozdziałach prezentuje uwarunkowania: podsystemowe, środowiskowe oraz systemowe. Te pierwsze zdefiniowane są jako interesy w zakresie bezpieczeństwa wyrażane przez poszczególne państwa członkowskie, właśnie z racji faktu wypływania ich ,z wnętrza państw członkowskich”, otrzymują miano podsystemowych. Interesy te składają się natomiast z elementów sprzecznych, komplementarnych oraz identycznych. Są to m.in.: przetrwanie i bezpieczeństwo państwa, jego suwerenność czy rozwój i jego tożsamość - w zakresie elementów identycznych. W przypadku sprzecznych interesów są to, np. interesy: zależne od położenia geopolitycznego, uzasadniane doświadczeniem historycznym czy pojmowaniem własnego bezpieczeństwa. Natomiast w zakresie interesów komplementarnych można m.in.: wyróżnić: przeciwdziałanie wyzwaniom i zagrożeniom bezpieczeństwa czy promowanie wspólnych wartości i celów (pokój, bezpieczeństwo, stabilność). Jako główne osie podziału wśród państw członkowskich można wskazać podział na: państwa o aspiracjach do odgrywania roli globalnej i pozostałe, państwa neutralne i prowadzace politykę zaangażowania w sojusze militarne oraz państwa powiązane blisko ze Stanami Zjednoczonymi Ameryki i optujące za współpracą z tym państwem oraz państwa będące przeciw bliskiej współpracy ze Stanami Zjednoczonymi Ameryki. 